\title{
Teksty i sny
}

Wojciech Owczarski

TEKSTY DRUGIE 2016, NR 5, S. 56-73

DOI: $10.18318 /$ td.2016.5.4

W ogromnie zróżnicowanej i wieloaspektowej dziedzinie wiedzy, jaką są dream studies, coraz częściej słyszy się głosy o konieczności wypracowania prawdziwie interdyscyplinarnych metod badawczych. $\mathrm{O}$ „prawomocności i potrzebie wpływających na siebie wzajemnie, w równomiernym stopniu, interdyscyplinarnych ujęć snu-i-literatury" ["the legitimacy of and necessity for mutually informed and balanced interdisciplinary approaches to dreams-and-literature"] już przeszło dwadzieścia lat temu pisała Carol Schreier Rupprecht ${ }^{1}$. I choć od tego czasu wiele się zmieniło, to nie da się ukryć, że badania nad snami w zdecydowanej większości przypadków są nadal prowadzone jednotorowo: psychologowie obserwują swoich pacjentów i na ogół nie interesują się abstrakcyjnymi zagadnieniami filozofów, filozofowie zachowują dystans wobec danych empirycznych, neurobiolodzy nie wyściubiają nosa ze swoich laboratoriów,

C. Schreier Rupprecht, K. Bulkley Reading Yourselfto Sleep:Dreams in/ and/as Texts, w: The Dream and the Text, ed. C. Schreier Rupprecht, State University of New York Press, Albany 1993, s. 2.

\section{Wojciech Owczar-}

ski - dr hab., prof.

UG. Pracownik

Instytutu Filologii

Polskiej Uniwersy-

tetu Gdańskiego.

Założyciel i kierownik

Pracowni Badań nad

Snem, Pamięcią i

Wyobraźnią działa-

jącej przy Wydziale

Filologicznym UG.

Członek International

Association for the

Study of Dreeams

(USA). Ostatnio

opublikował monografię Sennik polski.

Literatura, wyobraźnia

i pamięć (2014) oraz

zredagował tom

Dreams, phantasms

and memories (2015).

Kontakt: wowczar-

ski1@tlen.pl 
a antropolodzy i socjolodzy nie widzą świata poza badanymi przez siebie populacjami. Oczywiście we wszystkich tych dziedzinach obserwuje się przepływ wzajemnych inspiracji, niemniej badania snów zdecydowanie wykraczające poza jedną dyscyplinę zdarzają się niezmiernie rzadko.

Pojęcia inter-, multi- czy transdyscyplinarności zdążyły się już w świecie dzisiejszej nauki skompromitować, są bowiem często używane jako słowa-wytrychy, modne i nic nieznaczące hasła służące do podtrzymania dobrego samopoczucia przez rzesze ignorantów pławiących się w powierzchownym wszystkoizmie. Jednakże nie sposób zaprzeczyć, że w sferze marzeń sennych - zjawisk wciąż jeszcze tak słabo rozpoznanych i tak trudno dających się przypisać do jakiejś jednej dziedziny wiedzy o człowieku - ponadpartykularna perspektywa badawcza wydaje się niezbędna. Nie pojmie się natury snów, jeśli będzie się je traktować jako fenomeny czysto psychologiczne, czysto fizjologiczne, czysto kulturowe bądź czysto estetyczne. Przedstawiciele dream studies coraz wyraźniej zdają sobie z tego sprawę. Bodaj najlepiej widać to w ostatniej książce Ernesta Hartmanna, zmarłego w 2013 roku amerykańskiego psychiatry i psychoanalityka, jednego z najwybitniejszych i najwyżej cenionych specjalistów w dziedzinie snów. W swojej „współczesnej teorii śnienia" ["contemporary theory of dreaming”] Hartmann nie tylko łączy kompetencje psychiatry, psychologa i neurofizjologa, ale otwiera się też na dorobek nauk humanistycznych, zwłaszcza na propozycje retoryki i poetyki ${ }^{2}$.

Na temat tego, jak mogłyby (na przykład) wyglądać interdyscyplinarne badania snów w praktyce, można sobie wyrobić pogląd, czytając prace włoskich uczonych: lingwisty Sergia Pizziconiego i psychiatry Marca Zanassiego. Kierowany przez nich zespół badawczy opracował metodę stylistycznej analizy relacji snów zakładającą, że „sen powinien być traktowany jako rzeczywisty tekst literacki, wobec którego mogą być stosowane analizy stylu, narracji i struktury" ["dream is to be considered as a real literary text to which analyses on style, narratology and structure can be applied"] ${ }^{3}$. Wprawdzie głównym celem autorów jest poszukiwanie „korelacji między językowym kształtem opisów snów a psychopatologiczną przypadłością,

2 E. Hartmann The Nature and Function of Dreaming, Oxford University Press, New York 2011, S. 49-59.

3 S. Pizziconi, M. Zanassi, D. Silvi Dream Coding: Re-writing Dream Reports as an Object of Textual Analysis, w: Dreams, Phantasms and Memories, red. W. Owczarski, Z. Ziemann, Wydawnictwo UG, Gdańsk 2015, s. 114. 
na którą cierpi śniący" ["correlation between the linguistic realisation of dream reports and the psychopatology from which the dreamer is suffering" $]^{4}$, to niezwykle ciekawe byłoby zastosowanie tej metody również do snów literackich i porównanie stylistycznych właściwości snów w utworach wybranych pisarzy z właściwościami snów neurotyków, psychotyków czy psychopatów.

Celem mojego artykułu nie jest jednak ani teoretyczne uzasadnianie konieczności interdyscyplinarnych badań nad snem, ani nawet sugerowanie praktycznych metod ich prowadzenia. Chciałbym jedynie podważyć zasadność pewnego przeświadczenia, mocno zakorzenionego na gruncie literaturoznawstwa. Otóż sny przedstawiane w literaturze uznawane są często za „zmyślone”, tzn. „nieprawdziwe”, co zdaniem wielu badaczy sprawia, że nie można ich opisywać ani wyjaśniać przy pomocy narzędzi właściwych psychologii czy antropologii kulturowej, które to narzędzia służyć powinny jedynie do opisu snów „rzeczywistych”. Nierzadko słyszy się też głosy, że sny literackie - nawet jeśli pochodzą z rzeczywistych doświadczeń sennych autora - są tak dalece „przetworzone” z powodu wymogów konwencji literackiej czy kompozycyjnych zamysłów twórcy, że z prawdziwym snem nie mają zgoła nic wspólnego. Wyznawcy tego rodzaju poglądów traktują więc sen literacki jako li tylko tekst literacki, nie widząc potrzeby (a często wręcz możliwości), by przy jego analizie odwoływać się do wiedzy spoza zakresu teorii i historii literatury. Mam zamiar udowodnić, że jest to stanowisko niesłuszne i niemożliwe do obrony.

\section{I}

Nieufne i często pogardliwe nastawienie sporej części literaturoznawców (szczególnie w Polsce) do psychologizujących metodologii badawczych jest dobrze znane i opisane, nie ma więc powodu, żeby je tutaj szczegółowo prezentować. Jednym z najbardziej poruszających świadectw w tym względzie jest książka Danuty Danek o relacjach między literaturą i psychoanalizą .W tym zbiorze szkiców z różnych lat niemal na każdej stronie daje się słyszeć skargę autorki na niezrozumienie przez badaczy literatury, na ich lekceważący stosunek do psychoanalizy. O „braku psychoanalizy w kulturze

\footnotetext{
4 Tamże, s. 115.

5 D. Danek Sztuka rozumienia. Literatura i psychoanaliza, Wydawnictwo IBL PAN, Warszawa 1997.
} 
polskiej” pisał zajmująco Marek Bieńczyk ${ }^{6}$, a o jej „urwanych ścieżkach”Paweł Dybel?.

Nie sama jednak niechęć do psychoanalizy (w Polsce w ostatniej dekadzie wyraźnie zresztą słabsza) wpływa na wspomniany stosunek badaczy do literackich marzeń sennych. Nawet przedstawiciele "onejrokrytyki”, tzn. ci, którzy literackimi snami zajmują się chętnie i bez uprzedzeń, często traktują je jako zjawiska ze swej istoty odmienne od snów - nazwijmy je - „nieliterackich”.

Komparatysta Laurence M. Porter stwierdza ponad wszelką wątpliwość: "Sen rzeczywisty musi być oczywiście odróżniony od snu literackiego" ["The real dream must, of course, be distinguished from the literary dream"] ${ }^{8}$. Sądzi tak na podstawie zarówno rozważań teoretycznych, jak i analizy stylistycznej (do tej ostatniej wrócę w drugiej części szkicu). Zdaniem Portera - a wybrałem go tu jako głosiciela poglądów typowych, podzielanych przez wielu "onejrokrytyków" - różnica między snem rzeczywistym a snem literackim pojawia się na poziomie tego, co Freud nazwał "wtórnym opracowaniem”. „Pierwotne opracowanie - referuje Porter - jest nieświadomym procesem, który znajduje sposoby przedstawienia uczuć i myśli poprzez obrazy wizualne. Wtórne opracowanie jest w dużym stopniu bezrefleksyjnym przekładem tych obrazów na słowną relację snu przez śniącego, który podczas tego procesu bezwiednie eliminuje anomalie i tuszuje niezgodności. W snach literackich przeciwnie - wtórne opracowanie staje się nie tylko nieuniknionym efektem ubocznym, lecz także świadomym celem relacjonowania fantazji. Rozwija relację, a nie skraca, i to do tego stopnia, że krytyk literacki Albert Sonnenfeld ukuł termin 'trzecie opracowanie', by odróżnić sposób językowego opisu snów literackich od opisu snów rzeczywistych” ["Primary elaboration is the unconscious process that finds ways of representing feelings and thoughts via visual images. Secondary elaboration is the largely unreflective translation of these images into a verbal dream account by the dreamer, who during this process unwittingly eliminates anomalies and papers over discrepancies. In literary

6 M. Bieńczyk Czy romantyzm jest odpowiedzialny za brak psychoanalizy w kulturze polskiej?, w: Nasze pojedynki o romantyzm, red. D. Siwicka, M. Bieńczyk, Wydawnictwo IBL PAN, Warszawa 1995, s. 27-34.

7 P. Dybel Urwane ścieżki, czyli z dziejów psychoanalizy w Polsce zaborów i międzywojnia, w: tegoż Urwane ścieżki. Przybyszewski - Freud - Lacan, Universitas, Kraków 2000, s. 17-44.

8 L.M. Porter Real Dreams, Literary Dreams, and the Fantastic in Literature, w: The Dream and the Text, s. 33 . 
dreams, in contrast, secondary elaboration becomes not only the inevitable by-product, but also the conscious aim of the reporting of fantasies. Rather than abridging, it expatiates, to the point that the literary critic Albert Sonnenfeld proposed the term 'tertiary elaboration' to distinguish the linguistic encoding of literary dreams from that of real dreams"] .

Otóż właśnie na tak rozumiane pojęcie „trzeciego opracowania” nie sposób się zgodzić. Nie da się ani założyć, ani udowodnić, że „opracowanie” marzenia sennego na potrzeby literatury jest czymś ze swej istoty odmiennym od „opracowania” snu na użytek prywatny, np. w nieprzeznaczonych do publikacji notatnikach snów czy po prostu w celu opowiedzenia snu żonie czy terapeucie. W każdym wypadku będzie to relacja zniekształcona. Na czym jednak miałoby się opierać przeświadczenie, że w snach literackich zniekształcenie to będzie większe niż w snach rzeczywistych?

Już Freud przyznaje, że „nasze wspomnienie nie tylko odtwarza sen wyrywkowo, lecz także niewiernie, w sposób zafałszowany"10. Nie widzi w tym jednak nic, co „objaśnianie marzeń sennych” mogłoby uczynić bezpodstawnym. Zniekształcenie snu Freud traktuje jako jeden z elementów „pracy” marzenia sennego, a konkretnie - właśnie jako element „wtórnego opracowania". Zachodzą w nim te same zjawiska, co w trakcie powstawania snu, tzn. zniekształcające działanie cenzury. Nie jest to działanie dowolne czy przypadkowe, lecz jak najbardziej znaczące. Dlatego też „zmiany, jakim podlega marzenie senne w trakcie redakcji dokonywanej na jawie [...], pozostają [...] w związku skojarzeniowym z treścią, której miejsce zajmują, i służą do tego, by wskazać nam drogę wiodącą do tej treści, która z kolei sama może stanowić zastępstwo jakiejś innej treści"11.

Redakcja snu (i wynikające z niej zniekształcenie) jest zatem według Freuda niejako wpisana w sam sen, jest jego nieuchronnym przedłużeniem czy dopełnieniem. Nie oddala nas od snu, lecz „wskazuje drogę do jego treści". Naprawdę nie ma powodu, żeby zniekształcenia dokonywane przez pisarzy uważać za wyjątek od tej reguły (sam Freud, jak wiadomo, interpretował literackie sny, traktując je na równi ze snami rzeczywistymi) choćby dlatego, że zniekształcenia relacji snu (literackiej czy nie) nie da się zmierzyć. Obcujemy przecież wyłącznie z relacjami, do snu "samego w sobie”

9 Tamże, s. 37-38.

10 S. Freud Objaśnianie marzeń sennych, przeł. R. Reszke, KR, Warszawa 1996, s. 432.

11 Tamże, s. 434. 
po przebudzeniu nie mamy już dostępu. Możemy zakładać, że każda relacja snu jest z natury rzeczy zniekształcona, ale przecież nie możemy ocenić, do jakiego stopnia. Nie istnieje wszak „oryginal”, z którym relację moglibyśmy porównać. Z tego powodu psycholog-kognitywista Calvin Hall w 1966 roku zaproponował słynną definicję snu: „sen jest tym, co dana osoba opisuje, gdy poprosi się ją o opowiedzenie snu, z wyłączeniem komentarzy i interpretacji"12. Nie był to, rzecz jasna, wynik filozoficznego namysłu nad istotą snu, a jedynie praktyczny postulat badacza. Hall odróżniał sny „doświadczane” od snów „zapamiętanych”, a te z kolei od snów „opowiedzianych”. Pisał jednak: „Tylko sen opowiedziany istnieje obiektywnie, jako że nie sposób powiedzieć, o czym człowiek śnił ani co zapamiętał, dopóki nie opisze tego słowami" [„It is only the reported dream that has any objective existence, since there is no way of telling what a person has dreamed or what he remembers until he describes it in words”] ${ }^{13}$. I w innym miejscu: „Bezowocne jest dociekanie, na ile narracja snu odpowiada oryginałowi, ponieważ oryginalny sen nie może być zapisany” [„It is fruitless to ask how much the dream narrative resembles the original dream because the original dream cannot be transcribed"] ${ }^{14}$.

Z podejścia takiego wynika, że nie tylko literaturoznawcy, ale również psychologowie, badając sny, obcują w gruncie rzeczy wyłącznie z tekstami. (O tym, że każdy sen jest tekstem, przekonuje także Patricia Kilroe w artykule Sen jako tekst, sen jako narracja) ${ }^{15}$. Czy jest zatem sens upierać się, że sny rzeczywiste od literackich dzieli jakaś nieprzekraczalna granica? Jean Bellemin-Noël już w 1979 roku pisał w słynnym eseju Jak „psychoanalizować" sen Swanna: „Rodzi się pokusa, by w imię wspólnej tekstualności ostatecznie odrzucić różnicę między snem wyobrażonym, snem z fikcji artystycznej i rzeczywistym snem człowieka, który opowiada, co mu się śniło"16.

Oczywiście w wypadku literatury mamy do czynienia z konwencjami, raz mniej, raz bardziej sztywnymi, narzucającymi autorowi sposób wypowiedzi

12 1966, s. 18. Cyt. za: O. Vedfelt Wymiary snów. Istota, funkcje i znaczenie marzeń sennych, przeł. P. Billig, Wydawnictwo Psychologii i Kultury Eneteia, Warszawa 1998, s. 146.

C.S. Hall, V.J. Nordby The Individual and His Dreams, New American Library, New York 1972, s. 12.

C.S. Hall The Meaning of Dreams, McGraw-Hill Book Company, New York 1966, s. 11.

P. Kilroe The Dream as Text, the Dream as Narrative „"Dreaming” 2000 No. 3.

J. Bellemin-Noël Jak „psychoanalizować” sen Swanna, przeł. W. Krzemień, w: Psychoanaliza i literatura, red. P. Dybel, M. Głowiński, słowo/obraz terytoria, Gdańsk 2001, s. 206. Pierwodruk 1979. 
czasem nawet wbrew jego woli czy świadomości. Tak zwane konwencje oniryczne bywają, na domiar złego, szczególnie sztywne. Tyle że, jak dobrze wiadomo, konwencje dopadają nas wszędzie. Utarte sposoby wyrażania myśli, przyzwyczajenia i oczekiwania w tej dziedzinie - to zjawiska zmienne historycznie i kulturowo, od których uciec nie sposób w życiu codziennym, nie tylko w literaturze. Znowu więc trudno by w tym względzie wyznaczyć granicę między literacką a nieliteracką relacją snu. Przekonująco piszą o tym Guido Almansi i Claude Béguin we wstępie do swojej antologii snów w literaturze: „Oto jeden z paradoksów literackich snów. Z jednej strony literacki sen jest dokumentem sztucznym, gdyż został zmanipulowany przez pisarza zgodnie z zasadami retorycznej i narracyjnej strategii. Z drugiej strony jest dokumentem naturalnym, ponieważ są to te same zasady, które stosujemy każdego ranka, gdy po przebudzeniu próbujemy ‘naturalnie’ przywołać sen sprzed paru godzin: dla siebie, dla małżonka albo dla przyjaciela, lub też dla psychologa w czasie eksperymentu nad snem REM w laboratorium. Gdy mowa o snach, absurdalne rozróżnienie pomiędzy dyskursem naturalnym a kulturowym znika, bo wszystko jest kulturą, zarówno w sferze pamięci, jak i w dziedzinie słownej reprodukcji sennego doświadczenia” [„This is one of the paradoxes about literary dreams. On the one hand, a literary dream is an artificial document since it is manipulated by the writer according to the rules of rhetoric and narrative strategy. On the other hand, it is a natural document since these rules are the same ones that we apply every morning when we wake up and try to evoke the dream of the past hours 'naturally': for ourselves, for a spouse or a friend; or for a psychologist after a REM experiment in a laboratory. Where dreams are concerned the absurd distinction between natural and cultural discourse disappears because everything is culture, in the memory as well as in the verbal reproduction of the dream experience"] ${ }^{17}$.

Literackie sny, mimo że są podporządkowane najrozmaitszym strategiom pisarskim, mogą zachowywać oniryczne właściwości, tzn. - nie różnią się z założenia od innych, „zwykłych” relacji snów. Można je więc z powodzeniem poddawać takim samym zabiegom interpretacyjnym, jakim poddaje się „zwykłe" sny. Innymi słowy, nowoczesne podejście do snów w literaturze musi być podejściem interdyscyplinarnym. Nie może zamykać się w tradycyjnych

17 G. Almansi, C. Béguin Theatre of Sleep: an Anthology of Literary Dreams, Pan Books, London 1987, S. 9. 
kategoriach poetyki, lecz powinno pozostawać otwarte na ustalenia i inspiracje płynące $z$ innych dziedzin dream studies.

Przekonanie takie widoczne jest na szczęście w pracach wielu badaczy literackich snów. Carol Schreier Rupprecht tak charakteryzuje nowe tendencje w „onejrokrytyce”, rozwijające się od lat 9o. XX wieku: „Onejrokrytyka [...] dzieli wiele podstawowych, choć elastycznych założeń z innymi dziedzinami w obrębie nowej humanistyki śnienia. Założenia takie nie uprzywilejowują żadnej konkretnej perspektywy czy teorii. Przeciwnie, stawiają na podejścia bardziej dynamiczne niż ugruntowane, bardziej globalne niż etnocentryczne, bardziej zadające pytania niż narzucające odpowiedzi, bardziej zanurzone w historycznym kontekście niż zmierzające do uniwersalistycznych uogólnień, bardziej komparatystyczne i interdyscyplinarne niż ograniczone do jednej tradycji kulturowej czy dyscypliny. Krótko mówiąc, onejrokrytyka w swoim najlepszym wydaniu będzie w stanie w pełni objąć wieloznaczne i wielowartościowe zjawiska, które łączą sen, język i literaturę” ["Oneirocriticism [...] shares several foundational but flexible premises with other disciplines within the new humanities of dreaming. Such premises do not privilege any single point of view or school of theory. Instead they seek to foster approaches which are more dynamic than fixed, more globally inclusive than ethnocentric, more interrogatory than prescriptive, more historically contextualized than universally generalized, and more comparative and interdisciplinary than limited to a single cultural tradition or discipline. In short, oneirocriticism at its best will be capable of engaging fully the polysemous and polyvalent phenomena that bind together dream, language, and literature" $]^{18}$.

Do podejmowania interdyscyplinarnych studiów nad snem w literaturze zachęcają także prace wykazujące pokrewieństwa (genetyczne, strukturalne, lingwistyczne, fantazmatyczne) między marzeniem sennym i dziełem literackim. Warto, jak sądzę, przypomnieć dwie spośród nich. Montague Ullman, psychiatra o orientacji freudowskiej, w 1969 roku opublikował artykuł pod tytułem Sen jako metafora w ruchu (w którym nietrudno usłyszeć aluzję do terminu "dzieło w ruchu" z wydanego w 1962 roku Dzieła otwartego Umberta Eco). Wskazuje w nim na potrzebę „rozwoju i użycia takich technik tłumaczenia sennej metafory, które nie pochodziłyby z określonych systemów teoretycznych ani nie byłyby przez nie ograniczone” [,the development and 
application of techniques for translating the dream metaphor that are not derived from or limited by specific theoretical systems"19. Miejsca wspólne snu i literatury bardzo wnikliwie przedstawia literaturoznawca Bert O. States w wydanej w roku 1993 książce Śnienie a opowiadanie historii. Dowodzi w niej, że „śnienie jest pierwotną formą wszystkich fikcjonalnych opowieści” ["Dreaming is the ur-form of all fiction”] ${ }^{20}$. (Już we wcześniejszej o pięć lat książce Retoryka snów States przekonywał, że „sny są rodzajem proto-retoryki, jeszcze-nie językiem”, są „czymś wcześniejszym od retoryki, czymś, z czego retoryka ostatecznie wyrosła” ["Dreams are a kind of proto-rhetoric, not yet a language”; ,something prior to rhetoric, something on which rhetoric was eventually founded"] ${ }^{21}$ ). Co znamienne, States formułuje interdyscyplinarne credo: „Z całą pewnością temat snów i śnienia może stworzyć jedną z niewielu wspólnych przestrzeni zainteresowań dla humanistów i badaczy eksperymentalnych. Wierzę, że wiele można osiągnąć dzięki uważnemu wymienianiu się tym, co humaniści mają do powiedzenia o naszych twórczych dziełach, a badacze z kręgu kognitywistyki czy neurologii o tworzących je synapsach" ["Indeed, the subject of dreams and dreaming may constitute one of the few areas of mutual concern between humanists and scientists, and it is my belief that there is much to be gained by a cautious exchange of what humanists are saying about our creative productions and what cognitive scientists and neuroscientists are discovering about the synapses that produce them"] ${ }^{\mathbf{2 2}}$.

Niestety wielu badaczy - zwłaszcza w Polsce - nie chce zaakceptować takiego punktu widzenia. Dowodem na to może być - wartościowy skądinąd i poniekąd pionierski - tom Oniryczne tematy i konwencje w literaturze polskiej w XX wieku, zredagowany w 1999 roku przez Ilonę Glatzel, Jerzego Smulskiego i Annę Sobolewską. Już sam tytuł wskazuje, że literackie sny interesowały autorów głównie jako "tematy” i „konwencje”. Lektura tomu potwierdza, że w większości składających się nań szkiców sen był traktowany wyłącznie jako „motyw”, „model”, ,pierwiastek”, „wątek”, ,temat”, ,środek wyrazu”, element „poetyki” bądź „konwencji”. Wielu autorów wyciągnęło chyba zbyt daleko idące wnioski z pochodzącej z 1973 roku wypowiedzi Aleksandry

19 M. Ullman Dreaming as Metaphor in Motion, „Archives of General Psychiatry” 1969 No. 21, s. 696. wodruk 1993. 
Okopień-Sławińskiej: „Sen utrwalony i wysłowiony [...] przemienia się w fikcjonalną konstrukcję literacką, uformowaną całkowicie w [...] materii utworu i poddaną prawom sztuki pisarskiej. Wszystkie zatem sposoby kształtowania iluzji sennej mają naturę literackich konwencji, niezależnie od tego, w jakiej mierze naśladują właściwą strukturę sennego marzenia"23. W świetle przedstawionych wyżej ustaleń i obserwacji niepodobna mówić ani o „iluzji sennej” w wypadku literatury, ani o „właściwej strukturze" snu rzeczywistego. Sen literacki zachowuje, rzecz jasna, wszelkie właściwości tekstu literackiego, ale jednocześnie nie traci (a w każdym razie nie musi tracić) wszelkich właściwości snu²4.

\section{II}

Wspomniany Laurence M. Porter stara się dowieść, że literacki zapis snu różni się od nieliterackiego również $\mathrm{w}$ warstwie stylistycznej. Niestety zadowala się w tym względzie jednym jedynym przykładem - mianowicie porównuje zapis własnego snu z opisem snu Dymitra z Braci Karamazow Dostojewskiego. Stwierdza, że jego zapis jest krótki, konstrukcja zdań najprostsza z możliwych, słownictwo również jest proste i konkretne, a relacja utrzymana wyłącznie w czasie teraźniejszym, nie ma w niej czasowników modalnych ani przysłówków, a nieliczne przymiotniki mają silny ładunek emocjonalny (co pozwala uniknąć opisywania emocji wprost). Tekst Dostojewskiego z kolei aczkolwiek również niedługi - jest skonstruowany zupełnie inaczej: składa się z jednego tylko, za to wielokrotnie złożonego zdania, roi się w nim od synonimów i powtórzeń wzmagających efekt melodramatyczny, ton uczuciowy snu oraz intencje bohaterów są nazywane po imieniu (co wedle Portera nie zdarza się w relacjach snów rzeczywistych ${ }^{25}$.

Tym stylistycznym analizom nie sposób nic zarzucić. Szkoda tylko, że na ich podstawie Porter formułuje wnioski ogólne, sugerując, że zaobserwowane przez niego różnice są charakterystyczne dla wszystkich (czy niemal wszystkich) przypadków. Nietrudno, rzecz jasna, zadać kłam temu naiwnemu przeświadczeniu - wystarczy zgromadzić nieco więcej przykładów. Jeśli za chwilę to uczynię, to przecież nie po to, żeby polemizować z Porterem, lecz

23 A. Okopień-Sławińska Sny i poetyka, „Teksty” 1973 nr 2.

24 Piszę o tym szerzej w: W. Owczarski Sennik polski. Literatura, wyobraźnia i pamięć, słowo/obraz terytoria, Gdańsk 2014, s. 27-34. 
żeby unaocznić ogromną różnorodność stylistyczną wielorakich (literackich i nieliterackich) relacji snów, między którymi żadnych granic wytyczyć się nie da.

Zacznijmy od Lechonia, który w swoim Dzienniku często notował sny. Oto jeden z nich: „Było to jakieś wielkie zebranie, na którym Romain Rolland silił się przypomnieć sobie jak pacjent u psychoanalityka - jakieś decydujące, najważniejsze zdarzenie. Cała sala, w tym Jules Romains czekali na to z zapartym oddechem, pomagając Romain Rollandowi do przypomnienia sobie tego magicznego zaklęcia. W pewnej chwili zawołał on z radością: 'A! A!' I cała sala odetchnęła i zatrzęsła się od oklasków"26. A oto sen mojej studentki (w styczniu 2016 roku poprosiłem dwunastoosobową grupę studentów o zanotowanie jednego bądź dwóch z „najświeższych” snów, nie informując ich, do jakiego celu mi te zapisy posłużą): „W Sopocie na Monciaku przed KFC jest spotkanie studentów filologii polskiej. Głównym gościem, który ma opowiadać o sobie, jest Antoni Libera, a drugim też znany pisarz, ale nie pamiętam jak się nazywa i wstydzę się, że nie mogę sobie przypomnieć jego nazwiska, bo wszyscy dookoła traktują go z szacunkiem, a nawet uwielbieniem. Spotkanie i dyskusję prowadzi profesor Owczarski. Mówi, że będziemy oglądać film, na podstawie jednej z książek Libery i możemy wybrać jaki chcemy. Wśród studentów, na samym środku, na ogromnej kanapie, siedzi dziewczyna, której nie lubię i oczywiście ona krzyczy, że chcemy oglądać Madame. Myślę sobie, z pogardliwym uśmieszkiem, że powiedziała tak, bo nie zna żadnego innego utworu Libery. Budzę się z myślą, że ja też nie znam nic prócz Madame, ale że mam sen na środowe seminarium". (Pisownia oryginalna).

Oba sny można by nazwać „branżowymi”: zarówno znany poeta, jak i studentka polonistyki śnią o spotkaniach z pisarzami. Wiarygodność obu relacji wydaje się porównywalna i raczej wysoka: prawdopodobieństwo, że Lechoń wymyślił swój sen na potrzeby dziennika, nie jest chyba większe od prawdopodobieństwa, że studentka sprokurowała sen na potrzeby seminarium (umieszczając w nim swojego profesora). Z całą pewnością relacja studentki nie robi wrażenia mniej „literackiej” niż relacja Lechonia. W tekście studentki składnia jest bardziej wyrafinowana, dbałość o elegancję i przejrzystość wypowiedzi rzuca się w oczy. Autorka świadomie buduje nastrój, stosuje efekty gradacji („traktują go z szacunkiem, a nawet uwielbieniem”), stopniowo doprecyzowuje miejsce wydarzeń („wśród studentów, na samym środku, na ogromnej kanapie, siedzi dziewczyna”), w sposób dość zniuansowany opisuje 
swoje uczucia („wstydzę się, że nie mogę sobie przypomnieć”, ,nie lubię,,,,myślę sobie, z pogardliwym uśmieszkiem"). Całość kończy się dowcipną pointą.

W odróżnieniu od tekstu studentki relacja Lechonia utrzymana jest w czasie przeszłym i nie mówi nic o samym śniącym „ja” - przedstawia sytuację niejako obiektywnie, nie informując, czy śniący jest jej uczestnikiem czy tylko obserwatorem. Może więc w tym leży różnica między literackim a nieliterackim opisem snu? Nic podobnego! Spójrzmy na opis Adama Wiedemanna z jego książki Sceny tóźkowe, składającej się wyłącznie z krótkich relacji snów (o których przecież nie wiemy, czy są faktycznie snami autora, czy też zostały wymyślone): „Chodzimy normalnie na te Konfrontacje, ale filmy zupełnie inne, m.in. adaptacja Ziemi Ulro, w dwóch częściach: w pierwszej Czesław Miłosz, mieszkający z ciotką w domku na skalnym urwisku, zrzuca tę ciotkę ze skały do morza. W części II próbuje jakoś uniknąć zasłużonej kary, udaje się do miasta, gdzie mu proponują posadę (i kryjówkę) w burdelu męskim. Duch ciotki ciągle go nawiedza i mówi, że już się niedługo wcieli i wtedy będzie się mścić, a wcielić się może w każdy przedmiot żywy i nieożywiony, np. w czyjś paznokieć u nogi. Miłosz rozmyśla, czy paznokieć da się zaklasyfikować jako osobny przedmiot. W końcu zbliża się moment wcielenia, finał filmu, i w tym właśnie momencie odwraca się do mnie ktoś z poprzedniego rzędu, okazuje się, że to jakiś doktorant, i pyta, czy w czwartek po świętach będą zajęcia, ja nie wiem, film się tymczasem kończy, wychodzimy, pytam Basię, w co się ta ciotka ostatecznie wcieliła, a Basia:

- W Georgesa Bataille'a"27.

To również jest sen „branżowy” (w snach Wiedemanna pojawia się plejada znanych postaci, głównie ze świata literatury i sztuki). Absurdalna przygoda Miłosza nie przesłania tu relacji o doświadczeniach śniącego „ja”. Opowiadający niczego nie wyjaśnia i nie dopowiada (nie wiemy, dlaczego Miłosz zabija ciotkę, dlaczego za schronienie wybiera burdel, ani co to ma wspólnego z Ziemią Ulro), relacjonuje przebieg wydarzeń bez żadnej wiedzy naddanej (co, jak pamiętamy, Porter wytykał Dostojewskiemu). Zdaniem Wojciecha Kuczoka „autor sprawia wrażenie, jakby posiadł umiejętność zapisywania snów w postaci krynicznej, niezmąconej świadomością przebudzenia"28. To prawda, trzeba jednak dodać, że taka „umiejętność” może być również uznana za stylizację. Weźmy pod uwagę ostatnie zdanie. Składa się ono z trzynastu członów i sprawia wrażenie mowy kolokwialnej, tak jakby opowiadający starał się

27 A. Wiedemann Sceny łóżkowe, Ha!art, Kraków 2005, s. 42-43.

28 Tamże, czwarta strona okładki. 
mówić szybko, nie dbając o retoryczne efekty, tak, żeby niczego nie zapomnieć. Ta sama wypowiedź podzielona na kilka odrębnych zdań nie miałaby już tej potoczystości. Można więc pytać, czy Wiedemann, zapisując sen na potrzeby literatury, stara się uniknąć nadmiernej „literackości”, czy też przeciwnie - stylizuje wypowiedź na kolokwialną, a przez to właśnie uwydatnia kreacyjną moc literackiej konwencji. Przyjęcie drugiej z tych możliwości wcale nie dowodzi, że literacka relacja snu utkana jest z innej materii niż relacja snu rzeczywistego. Nie jest przecież tak, że Wiedemann odwołuje się w swojej stylizacji do jakiegoś obiektywnie istniejącego wzorca mowy kolokwialnej, zarezerwowanej dla opowiadania snów w sytuacjach życia codziennego. Wiedemann odwołuje się co najwyżej do własnego wyobrażenia takiej mowy. Bo przecież żaden wzorcowy paradygmat opowiadania snów nie istnieje (tak jak istnieją paradygmaty mowy gwarowej czy środowiskowej). Relacje rzeczywistych snów - co jeszcze udowodnię - wpisują się w najrozmaitsze rodzaje dyskursów, często również będących stylizacjami. Być może moja studentka naczytała się właśnie Wiedemanna i swój opis snu starała się, bardziej czy mniej świadomie, ukształtować na wzór jego prozy. Wówczas jej (nieliteracki?) opis (rzeczywistego?) snu byłby naśladowaniem (literackiego?) dyskursu pisarza, który z kolei naśladuje hipotetyczny dyskurs „naturalnego” opowiadania snów np. przez studentów...

Podobne paradoksy można by mnożyć. Zamiast tego przytoczę kolejne zapisy snów. Oto tekst studenta z tego samego seminarium: „Cztery pokoje stąd mieszka Niewyobrażalne Zło. Oddalone o cztery pomieszczenia przedzielone drzwiami, które za każdym razem zamykam na klucz. Drzwi są nie do przejścia, mimo to Niewyobrażalne Zło forsuje je bez problemu. Za każdym razem udaje mi się bezpiecznie uciec z tego mieszkania. I za każdym razem bezpiecznie do niego wracam. Nie potrafię pożegnać się z nim; oraz z nią - z przeszłością. Uciekam przed nią, a ona powraca. W postaci Kobiety Marzeń, której owłosione nogi za każdym razem pieszczę coraz gorliwiej. Wiem, że przez te pieszczoty pozostanie ze mną na zawsze. Teraz leży przede mną, ja siedzę i pieszczę jej nogi. Niewyobrażalne Zło w postaci kłębów skondensowanej energii śpi daleko od nas. Nie potrafi przejść przez zamknięte drzwi. Czujemy się bezpieczni. Po raz pierwszy od dłuższego czasu będziemy mogli wyjść z mieszkania i bezpiecznie do niego wrócić". (Pisownia oryginalna).

Mamy tu do czynienia z konwencją literatury gotyckiej i fantastyki, a raczej ze świadomą zabawą tymi konwencjami (owłosione nogi Kobiety Marzeń). Podniosły nastrój, egzaltowany ton wypowiedzi (uzyskany m.in. przez wielokrotne powtórzenie formuły „za każdym razem” oraz przez intonacyjny, 
a nie logiczny podział wypowiedzi na zdania („a ona powraca. W postaci Kobiety Marzeń"), abstrakcyjne pojęcie Niewyobrażalnego Zła hiperbolizowane wersalikami i określeniami rodem z gatunku science fiction („w postaci kłębów skondensowanej energii") - wszystko to czyni tę relację jak najdalszą od potocznej.

Oczywiście może ktoś powiedzieć, że studenci kierunków humanistycznych są jednak specyficzni, skrzywieni zawodowo i że nie powinno się ich tekstów traktować na równi z zapiskami „normalnych” ludzi... Spójrzmy zatem na fragment kolejnej relacji: „Byłam na brzegu jeziora. Budowałam tratwę z jakimś mężczyzną. Na brzegu stała mała wieża strażnicza z daszkiem. Miałam za zadanie opisywać kredą jej poszczególne elementy: ścianka lewa, ścianka prawa, dach... Nagle zza spróchniałych desek wyłoniła się mała głowa konia z tułowiem węża. Wystraszyłam się. [...]" (Pisownia oryginalna). Próżno tu szukać retorycznych fajerwerków. Zdania są krótkie i proste, ton rzeczowy i chłodny, choć przecież skrzyżowanie konia z wężem to hybryda niecodzienna. Czy można jednak powiedzieć, że ten opis jest bardziej typowy dla relacjonowania snów rzeczywistych niż opisy poprzednich dwojga studentów? Bałbym się takich uogólnień. Każdy z tych opisów jest przecież zupełnie inny.

Żeby wyjść poza krąg studentów filologii, odwołam się do odmiennego źródła przykładów - do świadectw, które w latach 1973-1974 nadsyłali byli więźniowie obozu koncentracyjnego w Oświęcimiu na prośbę zespołu krakowskich psychiatrów. Dzięki uprzejmości Muzeum Auschwitz-Birkenau dysponuję całością tego materiału (jego fragmenty opublikował ostatnio dyrektor Muzeum, Piotr M.A. Cywiński $\left.{ }^{29}\right)$. Oto fragment relacji snu z czasów uwięzienia, zapisanej po latach, 18 grudnia 1974 roku:

... Z daleka widać było wieżę pośród czubu drzew -

... Na białej taśmie gościńca zostawialiśmy ślady umęczonych stóp,

... Z głuchej nostalgią piersi wzniósł się tryumfalny śpiew,-

... Przezwyciężyliśmy smętek, co za nami się wlókł...

$[\ldots]$

Z daleka - widać było przy drewnianych sztachetach Barwne plamy nasiąkłe zwycięskim wiosennym słońcem...

29 P.M.A. Cywiński Sny obozowe w pamięci ocalałych z Auschwitz, Państwowe Muzeum Auschwitz-Birkenau, Oświęcim 2016. 
Uprzedziła nas wieść - nadzieję wzbudziła w kobietach -,

Może ktoś z nas utuli ich serca pragnieniem drżące?...

$[\ldots]$

Rozsunąłem tłum - widziałem porzucone kostury...

Pójdę dalej!...

Zbudziłem się. Była mroczna noc...

Ach! Przeżyć na jawie sen taki po raz wtóry!...

Nie chciałem myśleć... zarzuciłem na głowę więzienny koc...

[...] (Pisownia oryginalna)

Ten trochę nieporadny wiersz wzrusza, gdy zna się jego genezę. Nie napisał go debiutujący poeta zabiegając o względy krytyki, lecz starszy człowiek (ksiądz), który w młodości przeżył piekło Oświęcimia. Trudno przypuścić, by swoje traumatyczne doświadczenia traktował li tylko jako pretekst do popisania się poetyckim kunsztem. Dlaczego więc zapisał swój sen wierszem, w dodatku siląc się na wyrafinowane metrum toniczne (z przewagą wersów sześciozestrojowych, trochę jak w polskim heksametrze), $\mathrm{z}$ bogactwem wszelkich tropów (w tym rozbudowanych metafor: „Barwne plamy nasiąkłe zwycięskim wiosennym słońcem")? Nie poznamy odpowiedzi na to pytanie. Może po prostu naczytał się Czechowicza albo Baczyńskiego? A może więzienny sen o powrocie w rodzinne strony zapamiętał jako przeżycie tak piękne i wzniosłe, że dla jego opisania nie mógł sobie wyobrazić formy innej niż kunsztowny wiersz? Może więc poetycki sztafaż nie jest tu żadnym ornamentem, literackim naddatkiem, przekłamaniem, zniekształceniem, „trzecim opracowaniem", lecz jest właśnie samą istotą sennego doświadczenia - doświadczenia, które w pamięci więźnia zapisało się jako równoważne poetyckiemu arcydziełu. Tak czy inaczej - nie sposób rozstrzygnąć, czy mamy tu do czynienia z relacją literacką czy nieliteracką. Sen jest (niemal niewątpliwie) rzeczywisty, ale i wiersz jest rzeczywisty...

Zobaczmy teraz, jak nieco podobny sen o powrocie do domu przedstawia pisarz „profesjonalista”, Gustaw Herling-Grudziński w Innym świecie: „Śniło mi się najczęściej [...], że późnym wieczorem wracam ze stacji w Kieleckiem do domu. I choć była już noc, widziałem dokładnie, jak gdyby w czarnym świetle, najpierw piaszczystą drogę obok toru, potem zagajnik, dużą polanę z opustoszałą willą, [...] i wreszcie drogę prowadzącą nad nasz stary, zarośnięty szuwarami staw. [...] Wieczór był chłodny, ale wysuszony całodziennym upałem, księżyc w pełni wisiał nad naszym starym młynem jak 
błyszczący dukat, oparłszy się lekko o iglicę piorunochronu, od strony łąk dolatywał krzyk dzikich kaczek i plusk żerujących karpi. [...] Otworzyłem ostrożnie furtkę ogródka i wspiąłem się na występ muru pod oknem; przy stole siedział ojciec, nasza gospodyni, obie siostry, brat z żoną i jej córką. Pukałem w szybę i w chwili, kiedy zrywali się wszyscy od stołu, aby mnie po tylu latach powitać, budziłem się na pryczy płacząc, z rękami przyciśniętymi kurczowo do serca" ${ }^{\text {"0 }}$.

Tu również sytuacja i sam sen wydają się rzeczywiste (Herling-Grudziński był faktycznie w łagrze i - pisząc Inny świat - raczej nie miał powodu, by zmyślić taki sen).W opisie snu nie brakuje literackich środków ekspresji ani znanych rekwizytów - jest tu nawet sentymentalno-gotycki księżyc w pełni, który w dodatku „wisiał [...] jak błyszczący dukat”. Oczywiście opis ten jest znacznie bardziej wartościowy z estetycznego punktu widzenia niż wiersz księdza z Oświęcimia, ale czy można między nimi postawić nieprzenikalną przegrodę? Czy można upierać się, że przynależą one do dwóch różnych, niepowiązanych ze sobą kategorii?

Sny o powrocie do domu zdarzały się obozowym więźniom często. Oto kolejny przykład - sen o alei kasztanowej, którą śniący pamiętał z dzieciństwa: „I znów byłem (we śnie) małym chłopcem, bawiłem się na alei kasztanowej, pełnej słońca i pogody. Była jesień. Złote liście kasztanów oświetlone promieniami słonecznymi, tworzyły prześliczny złoty baldachim nad aleją. Od czasu do czasu liście opadały na ziemię tworząc piękny wzorzysty dywan. Stałem u wejścia alei i byłem urzeczony pięknem, którego dotąd nie dostrzegałem". (Pisownia oryginalna). Autora tego opisu nie można posądzać o jakieś wygórowane ambicje literackie, ale przecież nie stroni on od poetyckich środków wyrazu (liście tworzące „złoty baldachim” czy „wzorzysty dywan”). Nie ogranicza się do deklaracji, że we śnie był „urzeczony pięknem”, lecz stara się to piękno uchwycić i uczynić niejako namacalnym dla odbiorcy tekstu. Podobną strategię można obserwować w wielu świadectwach byłych więźniów. Jeden z nich pisze: „W okresie późniejszym śniło mi się, że już wróciłem do domu. Były tam rozmaite sytuacje zapamiętane jako uroczystości rodzinne. Czasem przeważał pierwiastek uczuciowy - tkliwość miłości do matki, brata, ojca. Czasem głód sprowadzał obrazy suto zastawionego stołu, mnogości potraw, wreszcie bochenki chleba, pachnące urzekająco, z rumianą lśniącą skórką...". Początkowo opowiadający chce tylko relacjonować fakty, ale gdy dochodzi do chleba, nie może powstrzymać się od nadania opisowi bardziej 
plastycznego charakteru. Pragnie, żebyśmy ten chleb poczuli, bo tylko wtedy uchwycimy to, co w jego śnie najważniejsze ${ }^{31}$.

Jak widać, nawet najbardziej „potoczna” relacja snu nie musi być całkowicie "przeźroczysta” - często wskazuje na samą siebie i w tym sensie nie różni się od relacji stricte literackiej.

\section{III}

Pora zapytać, jakie konsekwencje mogą wynikać z ustalenia, że między literackim a nieliterackim opisem snu wyraźnej granicy wytyczyć się nie da. Po pierwsze, należy pozbyć się złudzenia, że sen opowiedziany w sekrecie „prostymi słowami” jest bliższy „oryginałowi” niż sen ujęty przez poetę w formę trzynastozgłoskowca. Po drugie, nie ma powodu, żeby w śnie literackim widzieć jedynie literaturę; przeciwnie, warto w jego analizie odwoływać się również do metod stosowanych przy objaśnianiu snów rzeczywistych. Ale i, po trzecie, w snach rzeczywistych należy dostrzegać aspekty literackie, przyglądać się konwencjom i strategiom językowym, którymi, świadomie bądź nie, posługuje się opowiadający. Po czwarte wreszcie, zamiast dzielić sny na literackie i rzeczywiste, lepiej szukać tego, co je łączy, i traktować wszelkie sny jako teksty kultury poddające się wielostronnemu, interdyscyplinarnemu oglądowi. 


\section{Abstract}

\section{Wojciech Owczarski}

UNIVERSITY OF GDAŃSK

Texts and Dreams

Owczarski argues that literary is indistinguishable from non-literary accounts of dreams. Given that we have no access to dreams as they are, as we always rely on textual relations, the boundary between a literary dream and a real one is unavoidably blurred. What follows is that dreams described in literature maintain all the qualities of a literary text as well as all the qualities of the dream. Hence they can (and should) be studied in an interdisciplinary context, including the methods used to interpret real dreams. Owczarski supports his thesis with theoretical reflections based on the latest research in the field of dream studies, as well as on stylistic analyses of a variety of literary and non-literary accounts of dreams.

\section{Keywords}

literary dream, real dream, text, stylistic analyses, theory of dreams 